\title{
ANALISIS PENGENDALIAN MANAJEMEN PERSEDIAAN DENGAN MENGGUNAKAN METODE ECONOMIC ORDER QUANTTY (STUDI KASUS DI PT. X)
}

\section{DRAJAT INDRAJAYA}

\author{
Program studi Teknik Industri \\ Fakultas Teknik dan Ilmu Komputer \\ Universitas Indraprasta PGRI \\ Jl. Raya Tengah Kel. Gedong, Pasar Rebo, Jakarta Timur \\ Email : drajat.indrajaya@unindra.ac.id
}

\begin{abstract}
Abstrak. Manajemen persediaan ditinjau dari Teknik Industri bertujuan untuk mengatur barang atau bahan yang disimpan ditempat tertentu yang nantinya dipakai sesuai dengan tujuan yang sudah ditentukan seperti proses produksi, penjualan, perakitan produk dan lainnya. Dari proses bisnis perusahaan, manjemen persediaan sangat perlu dilakuan untuk membuat kebijakan strategis yang didapatkan dari hasil laporan rugi-laba yang dipengaruhi biaya operasional perusahaan. Metode EOQ (Economic Order Quantity) merupakan teknik pengendalian persediaan dialam manajemen persediaan. Penelitian ini bertujuan untuk menelaah bagaimana kebijakan yang dilakukan PT.X dalam melakukan pengawasan terhadap persediaan bahan baku mesin diesel model TF 85 MLY untuk kelancaran proses produksi.Masalah yang perlu dipertimbangkan dalam penelitian ini adalah bagaimana mengendalikan kuantitas (unit) bahan yang akan diolah atau dibeli sebagai bagian (jumlah lot) sehingga seluruh biaya yang terkait dengan pengolahan atau pembelian menjadi minimum. Dari hasil perhitungan dengan menggunakan EOQ yang telah diterapkan pada material lokal kelompok A, pengeluaran dapat dihemat sebesar Rp. 24.114.173 dari biaya total yang dikeluarkan PT. X dalam setahun. Hasil perhitungan dengan atau tanpa menggunakan metode EOQ yang tidak terlalu signifikan, turut dipengaruhi oleh penerapan kebijakan PT. X dengan para pemasoknya yang belum sesuai, oleh karena masih banyaknya supplier yang tidak memenuhi standar PT. X baik dalam hal pengiriman maupun technical.
\end{abstract}

Kata kunci: EOQ, persediaan, bahan baku, kapasitas produksi, kebijakan srategis

Abstract. Inventory management in terms of Industrial Engineering aims to organize goods or materials stored in a certain place which will be used with the predetermined objectives such as the production process, sales, product assembly and others. From the company's business processes, inventory management is necessary to be undertaken to create a strategic policy derived from the income statement that is influenced by the company's operational costs. EOQ (Economic Order Quantity) method is inventory control technique in inventory management. This study aims to examine how the policy conducted PT.X in monitoring the inventory of raw materials diesel engine model TF 85 MLY for smooth production process. The problem to consider in this study is how to control the quantity (unit) of materials to be processed or purchased as part (lot amount) so that all cost associated with processing or purchasing become minimum.. From result of calculation by using EOQ which have been applied to local material of group A, expense can be saved equal to Rp. 24,114,173 of total cost incurred by PT. $X$ within a year. The results of calculations with or without using the EOQ method is not too significant, also influenced by the implementation of PT policy. $X$ with its suppliers that have not been suitable, because there are still many suppliers that do not meet the standards of PT. X both in terms of delivery and technical.

Keywords: EOQ, inventory, raw materials, production capacity, strategic policy 


\section{PENDAHULUAN}

Persediaan merupakan salah satu aset terpenting dalam banyak perusahaan karena nilai persediaan mencapai $40 \%$ dari seluruh investasi modal. Manajer operasional sangat memahami bahwa persediaan merupakan hal yang krusial. Di satu sisi, perusahaan selalu berusaha mengurangi biaya dengan mengurangi tingkat persediaan di tangan (on hand), sementara itu di sisi lain pelanggan menjadi sangat tidak puas ketika jumlah persediaan mengalami kehabisan (stock-out). Oleh karena itu perusahaan harus mengusahakan terjadinya keseimbangan antara investasi persediaan dan tingkat layanan pelanggan dan meminimalisasi biaya merupakan faktor penting dalam membuat keseimbangan ini.

Menurut Indroprasto, Erma Suryani didalam publikasi ilmiah dengan judul Analisis Pengendalian Persediaan Produk Dengan Metode EOQ Menggunakan Algoritma Genetika untuk Mengefesienkan Biaya Persediaan yang telah diterbitkan didalam Jurnal ITS Vol 1 (Sept 2012) ISSN: 2301-9271, Untuk dapat meminimalkan biaya persediaan diperlukan perencanaan yang baik dalam mengoptimalkan jumlah barang yang harus dipesan. Jika pengendalian berjalan dengan optimal, kebutuhan barang perusahaan dapat terpenuhi, dan perusahaan dapat meminimalkan total biaya persediaan. Yang harus diperhatikan dalam pengendalian persediaan adalah waktu kedatangan barang yang akan dipesan kembali.

Hal-hal yang terkait dengan hasil penelitian yang menggunakan EOQ telah dijelaskan oleh Gede Agus Darmawan, Wayan Cipta, Ni Nyoman Yulianthin dalam publikasi ilmiah dengan judul Penerapan Economic Order Quantity (EOQ) Dalam Pengelolaan Persediaan Bahan Baku Tepung Pada Usaha Pia Ariawan di Desa Banyuning Tahun 2013 yang telah diterbitkan di dalam e-Journal Bisma Universitas Pendidikan Ganesha Jurusan Manajemen (Volume 3 Tahun 2015) yang di mana metode pembelian yang biasa dikenal dengan Economic Order Quantity (EOQ) dapat digunakan untuk mengatasi pemakaian yang berfluktuasi tersebut. Dalam perhitungannya, metode ini dipertimbangkan beberapa hal, antara lain jumlah kebutuhan bahan baku, biaya pemesanan dan biaya penyimpanan

PT. X berlokasi di Jl. Raya-Bogor Km 34,8 Desa Sukmajaya kota Depok Bogor Jawa Barat. Jenis mesin diesel yang diproduksi yaitu mesin diesel horizontal dengan pendingin air (Horizontal Water Cooled Diesel Engine) dan bertenaga 5,5 Hp, dan saat ini tenaganya mencapai $30 \mathrm{Hp}$.

Tabel 1. Jumah Produksi Mesin Diesel Tahun 2015

\begin{tabular}{cccccccccccccc}
\hline MODEL & JAN & FEB & MAR & APR & MAY & JUN & JUL & AUG & SEP & OCT & NOV & DEC & TOTAL \\
\hline TF55-H & 85 & 130 & 125 & 60 & 30 & 35 & 60 & 65 & 100 & 31 & 70 & 60 & 851 \\
TF55L & 30 & 54 & 44 & 115 & 50 & 0 & 0 & 0 & 0 & 10 & 28 & 60 & 391 \\
TF55R & 22 & 13 & 25 & 20 & 20 & 15 & 10 & 26 & 16 & 26 & 15 & 20 & 228 \\
TF65-H & 53 & 149 & 50 & 35 & 0 & 140 & 50 & 60 & 150 & 52 & 150 & 50 & 939 \\
TF65L & 222 & 95 & 122 & 400 & 150 & 0 & 10 & 185 & 200 & 164 & 152 & 280 & 1,980 \\
TF65R & 27 & 31 & 15 & 40 & 40 & 0 & 50 & 50 & 48 & 52 & 45 & 30 & 428 \\
TF70L-Y & 129 & 125 & 87 & 289 & 133 & 95 & 130 & 50 & 65 & 196 & 150 & 220 & 1,669 \\
TF75MH & 0 & 0 & 12 & 8 & 6 & 30 & 0 & 10 & 25 & 30 & 80 & 10 & 211 \\
TF75MR & 0 & 0 & 15 & 0 & 0 & 2 & 15 & 5 & 0 & 0 & 1 & 5 & 43 \\
TF80ML & 0 & 0 & 0 & 0 & 0 & 0 & 0 & 0 & 0 & 0 & 0 & 0 & 0 \\
TF85MRS & 0 & 0 & 0 & 0 & 6 & 0 & 0 & 0 & 0 & 0 & 0 & 0 & 6 \\
TF85MH & 41 & 33 & 106 & 0 & 0 & 0 & 10 & 45 & 81 & 46 & 75 & 20 & 457 \\
TF85MHS & 0 & 0 & 0 & 0 & 0 & 0 & 0 & 0 & 0 & 0 & 0 & 0 & 0 \\
TF85MLY & $\mathbf{8 5 4}$ & $\mathbf{7 7 0}$ & $\mathbf{8 3 2}$ & $\mathbf{5 5 5}$ & $\mathbf{3 7 8}$ & $\mathbf{4 8 4}$ & $\mathbf{4 0 0}$ & $\mathbf{1 , 0 4 2}$ & $\mathbf{2 5 3}$ & $\mathbf{1 , 2 3 7}$ & $\mathbf{1 , 2 6 2}$ & $\mathbf{1 , 2 3 8}$ & $\mathbf{9 , 3 0 5}$ \\
TF85MLYS & 10 & 20 & 70 & 30 & 50 & 0 & 45 & 118 & 110 & 125 & 200 & 250 & 1,028 \\
TF85MR & 15 & 14 & 34 & 0 & 15 & 30 & 20 & 21 & 30 & 6 & 20 & 25 & 230
\end{tabular}




\begin{tabular}{|c|c|c|c|c|c|c|c|c|c|c|c|c|c|}
\hline TF105MH & 54 & 55 & 40 & 45 & 10 & 70 & 20 & 60 & 0 & 19 & 30 & 45 & 448 \\
\hline TF105ML & 65 & 66 & 155 & 50 & 140 & 120 & 60 & 65 & 70 & 0 & 5 & 80 & 876 \\
\hline TF105MR & 32 & 35 & 70 & 85 & 70 & 10 & 20 & 54 & 50 & 0 & 45 & 20 & 491 \\
\hline TF115MH & 97 & 15 & 10 & 3 & 3 & 0 & 7 & 5 & 5 & 1 & 5 & 5 & 156 \\
\hline TF115MR & 2 & 6 & 2 & 2 & 3 & 2 & 2 & 5 & 5 & 0 & 2 & 5 & 36 \\
\hline $\begin{array}{c}\text { TF105MR- } \\
\text { E }\end{array}$ & 0 & 0 & 3 & 0 & 8 & 7 & 4 & 0 & 2 & 0 & 0 & 0 & 24 \\
\hline $\begin{array}{c}\text { TF115MR- } \\
\text { E }\end{array}$ & 0 & 0 & 0 & 0 & 0 & 0 & 3 & 0 & 0 & 0 & 0 & 0 & 3 \\
\hline TF135H & 7 & 4 & 0 & 19 & 3 & 5 & 5 & 25 & 20 & 0 & 6 & 5 & 99 \\
\hline TF135R & 6 & 1 & 0 & 21 & 9 & 0 & 0 & 5 & 15 & 70 & 15 & 5 & 147 \\
\hline TF135R-E & 0 & 0 & 0 & 0 & 0 & 0 & 0 & 0 & 0 & 0 & 0 & 0 & 0 \\
\hline TF155H & 33 & 56 & 122 & 55 & 0 & 10 & 250 & 55 & 75 & 45 & 90 & 100 & 891 \\
\hline TF155R & 6 & 27 & 38 & 80 & 30 & 20 & 55 & 10 & 30 & 8 & 40 & 40 & 384 \\
\hline TF155R-E & 2 & 2 & 3 & 0 & 3 & 5 & 0 & 0 & 0 & 0 & 0 & 0 & 15 \\
\hline TS190-R & 5 & 13 & 40 & 17 & 12 & 35 & 25 & 25 & 10 & 0 & 40 & 30 & 252 \\
\hline $\mathrm{TS} 190 \mathrm{H}$ & 5 & 26 & 15 & 30 & 21 & 0 & 20 & 20 & 35 & 0 & 25 & 20 & 217 \\
\hline TS190R-E & 0 & 13 & 5 & 4 & 3 & 4 & 0 & 0 & 0 & 0 & 0 & 0 & 29 \\
\hline TS230-R & 44 & 30 & 60 & 15 & 24 & 55 & 44 & 40 & 10 & 26 & 45 & 25 & 418 \\
\hline $\mathrm{TS} 230 \mathrm{H}$ & 45 & 15 & 50 & 60 & 10 & 40 & 25 & 60 & 11 & 26 & 41 & 40 & 423 \\
\hline TS230H-N & 19 & 5 & 15 & 0 & 16 & 10 & 10 & 20 & 11 & 26 & 15 & 15 & 162 \\
\hline TS230H-V & 45 & 61 & 19 & 50 & 10 & 30 & 45 & 30 & 25 & 25 & 40 & 50 & 430 \\
\hline TS230R-E & 0 & 6 & 5 & 5 & 9 & 6 & 1 & 0 & 6 & 0 & 0 & 0 & 38 \\
\hline TF300H & 57 & 50 & 86 & 20 & 40 & 30 & 45 & 0 & 0 & 87 & 75 & 100 & 590 \\
\hline SSYY & 0 & 0 & 0 & 0 & 0 & 0 & 0 & 0 & 0 & 0 & 0 & 0 & 0 \\
\hline $\begin{array}{c}\text { SUB } \\
\text { TOTAL }\end{array}$ & 2,012 & 1,920 & 2,275 & 2,113 & 1,302 & 1,290 & 1,441 & 2,156 & 1,458 & 2,308 & 2,767 & 2,853 & 23,895 \\
\hline
\end{tabular}

Berdasarkan tabel 1 di atas dari keseluruhan model yang diproduksi PT. X, model TF 85 MLY merupakan model yang paling banyak permintaannya, berdasarkan data pada tahun 2015 hasil produksi khusus TF 85 MLY mencapai sebesar 9.306 unit. Permintaan yang cukup besar jika dibandingkan dengan permintaan model lainnya. Melihat peningkatan permintaan model TF 85 MLY setiap bulannya, maka diperlukan usaha untuk melancarkan kebutuhan produksi, yaitu dengan tersedianya persediaan bahan baku dalam jumlah yang tepat, dalam arti persediaan tersebut tersedia dalam jumlah yang tidak terlalu besar, maupun tidak terlalu kecil. Karenanya perlu suatu keputusan mengenai kapan persediaan harus dipesan serta berapa banyak jumlah persediaan bahan baku yang harus dipesan, sehingga total biaya persediaan bahan baku yang minimum, persediaan bahan baku dapat tersedia dalam jumlah yang sesuai dengan kebutuhan produksi.

Oleh karena itu berdasarkan latar belakang dan identifikasi yang telah diuraikan sebelumnya, maka yang menjadi pokok permasalahan dalam penelitian ini adalah (1) berapa jumlah per pesanan bahan baku mesin diesel model TF 85 MLY dengan menggunakan EOQ; (2) berapa besar total biaya persediaan mesin diesel model TF 85 MLY dengan menggunakan EOQ; (3) kebijakan-kebijakan apakah yang harus dilakukan perusahaan dalam rangka optimalisasi persediaan produksi.

Penelitian ini bertujuan untuk memberikan suatu gambaran mengenai kunci suatu keberhasilan pelaksanaan pengawasan persediaan, kepada perusahaan yang akan diterapkan pada pemenuhan bahan baku terhadap kelancaran proses produksi.

\section{Landasan Teori}

Menurut Donald J Bowersox, pengawasan persediaan (inventory control) adalah suatu prosedur mekanis untuk melaksanakan suatu kebijaksanaan persediaan. Aspek akuntabilitas dari pengawasan ini akan mengukur berapa unit yang ada di tangan pada suatu lokasi tertentu dan terus mengikuti penambahan dan pengurangan terhadap kuantitas dasarnya. 
Menurut Hani Handoko, perusahaan dapat menggolongkan jenis bahan menurut konsep Analisis ABC. Persediaan dibagi menjadi 3 kelas yaitu: Kelas A, merupakan barang-barang dalam jumlah unit berkisar 15 sampai 20\%, tetapi mempunyai nilai rupiah 60 sampai $90 \%$ dari investasi tahunan total dalam persediaan. Kelas B, merupakan barang-barang dengan jumlah fisik 30 sampai $40 \%$, tetapi nilai investasi tahunannya bernilai 10 sampai 30\%. Kelas C, merupakan barang-barang dengan jumlah fisik 40 sampai $60 \%$, tetapi hanya bernilai 10 sampai $20 \%$ dari investasi tahunan.

Analisis ABC adalah sebuah aplikasi persediaan dari prinsip Pareto. Prinsip Pareto menyatakan bahwa terdapat "sedikit hal yang penting dan banyak hal yang sepele". Tujuannya adaah membuat kebijakan persediaan memusatkan sumber daya pada komponen persediaan penting yang sedikit dan bukan pada yang banyak tetapi sepele. Tidaklah realistis untuk memonitor persediaan yang murah dengan intensitas yang sama sebagaimana dengan persediaan yang sangat mahal.

Pengawasan persediaan berhubungan dengan kegiatan mengatur persediaan persediaan bahan-bahan agar dapat menjamin kelancaran proses produksi secara efektif dan efisien. Dalam rangka pengaturan ini, perlu ditetapkan kebijakan-kebijakan yang berkenaan dengan persediaan, baik mengenai pemesannya maupun tingkat persediaan yang optimum. Mengenai pemesanan bahan-bahan perlu ditentukan bagaimana cara pemesanannya, berapa jumlah yang dipesan agar pemesanan tersebut ekonomis dan kapan pemesanan itu dilakukan. Sedangkan mengenai persediaan perlu ditentukan berapa besarnya persediaan penyelamat yang merupakan persediaan minimum, besarnya persediaan pada waktu pemesanan kembali dilakukan dan besarnya persediaan maksimum.

Metode EOQ merupakan model yang paling sering digunakan oleh banyak perusahaan. Menurut Assauri, Jumlah pemesanan ekonomis terletak dimana jumlah biaya pemesanan adalah sama dengan jumlah biaya penyimpanan, atau EOQ merupakan jumlah atau besarnya pesanan yang dimiliki

Rumusan EOQ yang biasa digunakan adalah seperti berikut:

$$
E O Q=\sqrt{\frac{2 D S}{H}}
$$

Keterangan:

EOQ = Jumlah yang paling efisien (ekonomis) untuk dipesan

$\mathrm{D}=$ Permintaan tahunan dalam unit untuk barang persediaan

$\mathrm{S} \quad=$ Biaya Pemesanan untuk setiap pesanan (Ordering Cost per Order)

$\mathrm{H}$ = Biaya Penyimpanan atau penggudangan per unit per tahun (Carriyng Cost)

Model EOQ ini dapat diterapkan bila anggapan-anggapan berikut ini dipenuhi:

1) Permintaan akan produk adalah konstan, seragam dan diketahui (determinatik).

2) Harga per unit produk adalah konstan

3) Biaya penyimpanan per unit per tahun $(\mathrm{H})$ adalah konstan

4) Biaya pemesanan per pesanan (S) adalah konstan

5) Waktu antara pesanan dilakukan dan barang diterima (Lead Time, L) adalah konstan.

6) Tidak terjadi kekurangan barang atau "back orders"

Besar jumlah persediaan penyelamat stock (Safety Stock) yang dimiliki perusahaan dipengaruhi oleh 2 faktor berikut ini, yaitu:

1) Penggunaan bahan baku rata-rata.

2) Faktor waktu atau Lead Time (Procurement Time).

Jika Lead Time dan rata-rata pemakaian selama lead time telah diketahui, maka cara mencari Safety Stock adalah sebagai berikut:

Safety Stock = Lead Time X Pemakaian Rata-rata

Setelah berapa banyak pesanan pesanan telah diputuskan, maka akan ditentukan kapan pemesanan akan dilakukan. Keputusan kapan untuk memesan pada umumnya dinyatakan dalam 
kaitan dengan sebuah titik pemesanan ulang (Reorder Point-ROP), yaitu tingkat persediaan dimana pemesanan harus dilakukan. Titik pemesanan ulang ditunjukkan sebagai:

\section{ROP = Jumiah Pemesanan Ekonomis $\times$ Safetv Stock}

Secara ideal, seharusnya persediaan minimum adalah nol dan persediaan maksimum adalah sebanyak yang secara ekonomis mencapai optimal, yaitu sesuai dengan perhitungan EOQ. Persis pada waktu barang habis, pemesanan barang sejumlah yang paling ekonomis datang. Tetapi ini perhitungan teori, artinya dalam kenyataannya tidak dapat dijamin bahwa perencanaan dapat secara sempurna terpenuhi. Ada kemungkinan pemakaian material berubah dan meningkat secara mendadak, ada kemungkinan material yang dipesan datang terlambat, dan sebagainya.

Jika tidak terjadi kekurangan persediaan, maka total biaya persediaan per tahun dapat dihitung dengan rumus berikut:

Total Biaya $=$ Total Biaya Pembelian + Total Biaya Pemesanan + Total Biaya Simpan

Dimana:

Total Biaya Pembelian = Harga (pieces) $\mathrm{x}$ Total Kuantitas Pembelian

Total Biaya Pemesanan = Biaya satu kali pesan $\mathrm{x}$ Frekuensi Pemesanan

Total Biaya Penyimpanan $=($ Rata-rata Persediaan/2) $\mathrm{x}$ Harga satuan $\mathrm{x} \%$ Biaya penyimpanan.

\section{METODE}

Penelitian ini merupakan format deskriftif studi kasus, karena studi ini dapat amat mendalam dan "menusuk" sasaran peneltian. Penelitian ini sesungguhnya hanya menggunakan kasus tertentu sebagai objek peneltian, yaitu hanya fokus pada mesin diesel dengan model TF 85 MLY, khusus persediaan yang termasuk klasifikasi Finished Good Material.

Analisa data kuantitatif dapat membentuk teori dan nilai yang dianggap berlaku di suatu tempat. Data yang didapat untuk kepentingan penelitian ini adalah data pemakaian bahan baku di PT. X tahun 2015, data mengenai harga bahan baku, data biaya pemesanan, dan penyimpanan bahan baku. Data tersebut kemudian dianalisis dengan pemakaian rumus untuk mendapat jumlah pemesanan ekonomis, dan waktu pemesanan yang paling tepat.

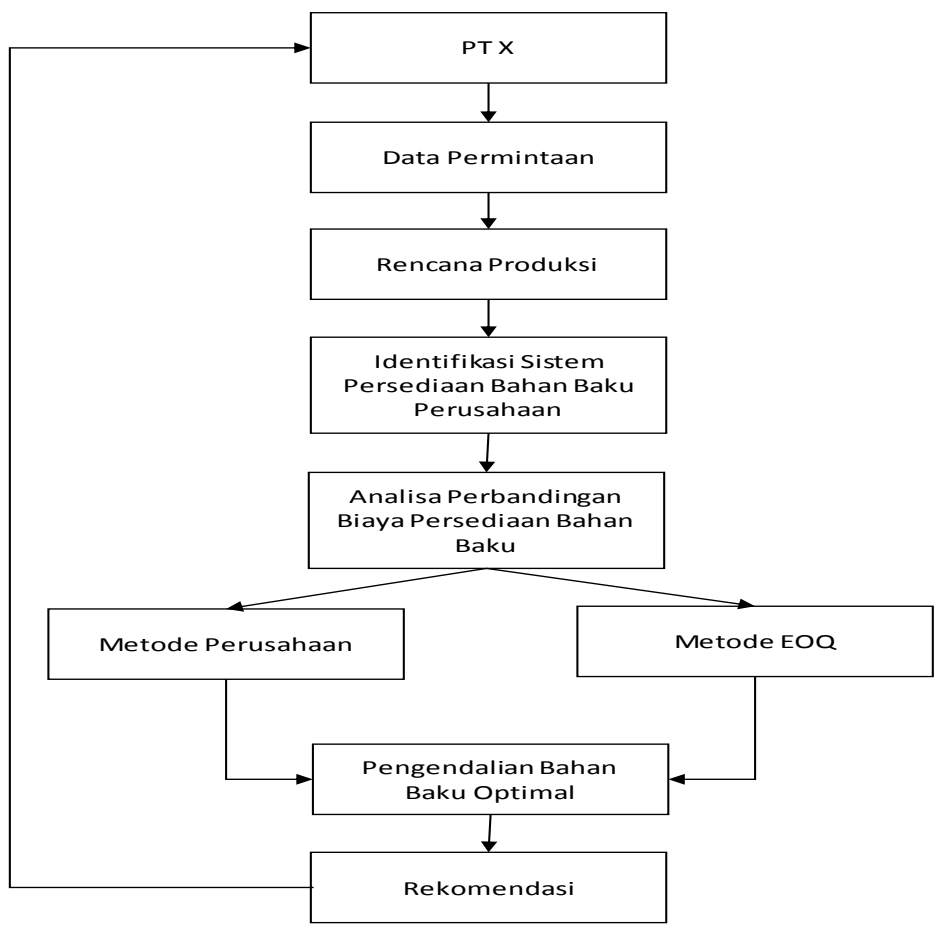


Gambar 1. Kerangka Berpikir Metodologi Penelitian

\section{HASIL DAN PEMBAHASAN}

Penerapan Klasifikasi ABC

Metode klasifikasi ABC ini mengelompokkan material yang digunakan untuk memproduksi mesin diesel dibagi ke dalam tiga kelompok berdasarkan fluktuasi permintaan pada saat produksi. Dengan metode ini maka setiap material model TF 85 MLY yang termasuk dalam Finished Good Material. disusun dalam suatu daftar. Daftar tersebut berisikan Nomor, Kode Material, Nama Material, Jumlah Pemakaian, Biaya per unit (piece). Dari daftar ini kemudian disusun daftar pengurutan material mulai dari total biaya yang terbesar sampai total biaya yang terkecil.

Tabel 2. Biaya Pembelian Material Tahun 2015

\begin{tabular}{clrrc}
\hline No. & Nama Material & Pembelian & $\begin{array}{c}\text { Biaya per } \\
\text { (Pieces) }\end{array}$ & $\begin{array}{c}\text { Harga } \\
\text { Pembelian } \\
\text { (Rp) }\end{array}$ \\
\hline 1 & RAD.CMP & 12,150 & 241,395 & $2,932,949,250$ \\
2 & FO TANK & 12,150 & 89,000 & $1,081,350,000$ \\
3 & SILENCER ASSY & 13,150 & 34,600 & $454,990,000$ \\
4 & DRAIN COCK,HRL & 32,500 & 13,300 & $432,250,000$ \\
5 & V-PULLEY RAD & 24,050 & 16,450 & $395,622,500$ \\
6 & GOVERNOR & 15,020 & 20,500 & $307,910,000$ \\
7 & GEVER & 14,150 & 18,322 & $259,256,300$ \\
8 & COAR CRANK & 11,420 & 19,300 & $220,406,000$ \\
9 & SCREEN,(OFW) & 13,540 & 12,181 & $164,930,740$ \\
10 & COLLAR COV.RAD & 45,500 & 2,900 & $131,950,000$ \\
11 & STAY,FO TANK & 12,761 & 11,910 & $151,983,510$ \\
12 & SPANNER 19X22 & 30,000 & 4,200 & $126,000,000$ \\
13 & SPANNER 14X17 & 30,000 & 3,165 & $94,950,000$ \\
14 & ELEMENT,FO STR & 29,500 & 3,400 & $100,300,000$ \\
15 & CYL.REAR COVER & 13,806 & 5,620 & $77,589,720$ \\
16 & TENS.PULLEY & 15,128 & 6,029 & $91,206,712$ \\
\hline & & & & \\
\hline
\end{tabular}

Biaya penyimpanan (Carrying Cost) adalah semua biaya yang disebabkan oleh PT. X oleh karena adanya penyimpanan material selama di gudang, seperti biaya pergudangan yang terdiri dari biaya pemeliharaan gudang dan lain-lain sebesar 5\% dari biaya untuk memperoleh material tersebut.

Setiap kali suatu material dipesan, PT. X menanggung biaya pemesanan (ordering costs). Biaya pemesanan PT. X adalah semua pengeluaran yang disebabkan oleh adanya kegiatan 
mendatangkan dari luar meliputi biaya yang terdapat pada Breakdown, seperti biaya angkut sebesar 15\% dari harga material, dan biaya administrasi sebesar Rp. 150,- (pieces). Besarnya biaya pemesanan PT. X selama tahun 2006 dapat dilihat pada tabel berikut.

\begin{tabular}{|c|c|c|}
\hline No. & Nama Material & $\begin{array}{c}\text { Biaya Pemesanan } \\
(\mathbf{R p})\end{array}$ \\
\hline 1 & RAD.CMP & $5,431,388$ \\
\hline 2 & FO TANK & $2,002,500$ \\
\hline 3 & SILENCER ASSY & 778,500 \\
\hline 4 & DRAIN COCK,HRL & 299,250 \\
\hline 5 & V-PULLEY RAD & 370,125 \\
\hline 6 & $\begin{array}{l}\text { GOVERNOR } \\
\text { LEVER }\end{array}$ & 461,250 \\
\hline 7 & GEAR CRANK & 412,245 \\
\hline 8 & COVER,RADIATOR & 434,250 \\
\hline 9 & SCREEN,(OFW) & 274,073 \\
\hline 10 & COLLAR COV.RAD & 65,250 \\
\hline 11 & STAY,FO TANK & 267,975 \\
\hline 12 & SPANNER 19X22 & 94,500 \\
\hline 13 & SPANNER 14X17 & 71,213 \\
\hline 14 & ELEMENT,FO STR & 76,500 \\
\hline 15 & CYL.REAR COVER & 126,450 \\
\hline 16 & TENS.PULLEY & 135,653 \\
\hline
\end{tabular}

\section{Perhitungan Economic Order Quantity (EOQ)}

Setelah mengetahui biaya-biaya yang terkandung di dalam persediaan bahan baku, PT. X dapat menghitung total biaya yang dikeluarkan untuk persediaan bahan baku selama satu tahun. Kemudian PT. X dapat melakukan perbandingan apabila menggunakan metode EOQ.

Tabel 4. Perbandingan Frekuensi Dengan dan Tanpa Metode EOQ

\begin{tabular}{|c|c|c|c|c|c|c|}
\hline \multirow[t]{2}{*}{ No. } & \multirow[t]{2}{*}{ Nama Material } & \multirow{2}{*}{$\begin{array}{c}\text { Biaya } \\
\text { Pemesanan }\end{array}$} & \multicolumn{2}{|c|}{ Tanpa EOQ } & \multicolumn{2}{|c|}{ Dengan EOQ } \\
\hline & & & Frek. & $\begin{array}{c}\text { Biaya } \\
\text { Pemesanan } \\
\text { (Rp) }\end{array}$ & Frek. & $\begin{array}{c}\text { Biaya } \\
\text { Pemesanan } \\
(\mathbf{R p})\end{array}$ \\
\hline 1 & RAD.CMP & $5,431,388$ & 6 & $32,588,325$ & 4 & $21,725,550$ \\
\hline 2 & FO TANK & $2,002,500$ & 6 & $12,015,000$ & 4 & $8,010,000$ \\
\hline
\end{tabular}




\begin{tabular}{rlrrrrr}
\hline 3 & SILENCER ASSY & 778,500 & 5 & $3,892,500$ & 4 & $3,114,000$ \\
4 & DRAIN COCK,HRL & 299,250 & 7 & $2,094,750$ & 6 & $1,795,500$ \\
5 & V-PULLEY RAD & 370,125 & 6 & $2,220,750$ & 5 & $1,850,625$ \\
6 & GOVERNOR & 461,250 & 8 & $3,690,000$ & 4 & $1,845,000$ \\
7 & LEVER & 412,245 & 8 & $3,297,960$ & 4 & $1,648,980$ \\
8 & GEAR CRANK & 434,250 & 9 & $3,908,250$ & 4 & $1,737,000$ \\
9 & SCREEN,(OFW) & 274,073 & 5 & $1,370,363$ & 4 & $1,096,290$ \\
10 & COLLAR COV.RAD & 65,250 & 8 & 522,000 & 7 & 456,750 \\
11 & STAY,FO TANK & 267,975 & 5 & $1,339,875$ & 3 & 803,925 \\
12 & SPANNER 19X22 & 94,500 & 7 & 661,500 & 6 & 567,000 \\
13 & SPANNER 14X17 & 71,213 & 7 & 498,488 & 6 & 427,275 \\
14 & ELEMENT,FO STR & 76,500 & 9 & 688,500 & 5 & 382,500 \\
15 & CYL.REAR COVER & 126,450 & 7 & 885,150 & 4 & 505,800 \\
16 & TENS.PULLEY & 135,653 & 7 & 949,568 & 4 & 542,610 \\
\hline
\end{tabular}

Perhitungan Persediaan Pengaman (Safety Stock)

Safety stock di sini berfungsi untuk memenuhi kebutuhan mendadak atau untuk memenuhi permintaan yang lebih besar dari yang biasanya, serta menghindari masalah dalam pemesanan dan pengiriman barang.

Tabel 5. Safety Stock Material (Finished Good)

\begin{tabular}{|c|c|c|c|c|c|}
\hline No. & $\begin{array}{c}\text { Kode } \\
\text { Material }\end{array}$ & Nama Material & $\begin{array}{l}\text { Rata-rata } \\
\text { Pemakaian } \\
\text { Perminggu }\end{array}$ & $\begin{array}{c}\text { Waktu } \\
\text { Tunggu } \\
\text { (Lead Time) }\end{array}$ & $\begin{array}{c}\text { Persediaan } \\
\text { Pengaman } \\
\text { (Safety Stock) }\end{array}$ \\
\hline 1 & $105300-44501$ & RAD.CMP & 238 & 8 minggu & 1,904 \\
\hline 2 & $\begin{array}{l}\text { 10540G- } \\
55020\end{array}$ & FO TANK & 238 & 4 minggu & 952 \\
\hline 3 & 105300-13511 & SILENCER ASSY & 252 & 8 minggu & 2,015 \\
\hline 4 & 900202-00110 & DRAIN COCK,HRL & 570 & 8 minggu & 4,563 \\
\hline 5 & $\begin{array}{l}\text { 10530G- } \\
21600\end{array}$ & V-PULLEY RAD & 432 & 8 minggu & 3,458 \\
\hline 6 & $105300-66300$ & $\begin{array}{l}\text { GOVERNOR } \\
\text { LEVER }\end{array}$ & 263 & 8 minggu & 2,106 \\
\hline 7 & $\begin{array}{l}10540 \mathrm{H}- \\
21200\end{array}$ & GEAR CRANK & 263 & 8 minggu & 2,106 \\
\hline 8 & $105400-44250$ & COVER,RADIATOR & 238 & 4 minggu & 952 \\
\hline 9 & $\begin{array}{l}\text { 10540G- } \\
44340\end{array}$ & SCREEN,(OFW) & 238 & 4 minggu & 952 \\
\hline
\end{tabular}




\begin{tabular}{rlllcl}
\hline 10 & $105300-44460$ & COLLAR COV.RAD & 864 & 8 minggu & 6,916 \\
11 & $105302-55240$ & STAY,FO TANK & 208 & 8 minggu & 1,663 \\
12 & $28110-190220$ & SPANNER 19X22 & 573 & 8 minggu & 4,587 \\
13 & $28110-140170$ & SPANNER 14X17 & 573 & 8 minggu & 4,587 \\
14 & $105370-55710$ & ELEMENT,FO STR & 513 & 8 minggu & 4,106 \\
15 & $\begin{array}{l}10530 G- \\
01480-M\end{array}$ & CYL.REAR COVER & 263 & 8 minggu & 2,106 \\
16 & $105300-44940$ & TENS.PULLEY & 238 & 4 minggu & 952 \\
\hline
\end{tabular}

Perhitungan Titik Pemesanan Kembali (Reorder Point)

Setelah berapa banyak pesanan pesanan telah diputuskan, maka akan ditentukan kapan pemesanan akan dilakukan. Keputusan kapan untuk memesan pada umumnya dinyatakan dalam kaitan dengan sebuah titik pemesanan ulang (Reorder Point-ROP), yaitu tingkat persediaan dimana pemesanan harus dilakukan.

Tabel 6. Titik Pemesanan Ulang (ROP)

\begin{tabular}{rllrrr}
\hline No. & Kode Material & Nama Material & EOQ & Safety Stock & $\begin{array}{c}\text { ROP } \\
\text { (Q Unit) }\end{array}$ \\
\hline 1 & $105300-44501$ & RAD.CMP & 3.337 & 1,904 & 5241 \\
2 & 10540 G-55020 & FO TANK & 3337 & 952 & 4289 \\
3 & $105300-13511$ & SILENCER ASSY & 3433 & 2,015 & 5448 \\
4 & $900202-00110$ & DRAIN COCK,HRL & 5167 & 4,563 & 9730 \\
5 & 10530 G-21600 & V-PULLEY RAD & 4498 & 3,458 & 7955 \\
6 & $105300-66300$ & GOVERNOR & 3510 & 2,106 & 5617 \\
7 & $10540 \mathrm{H}-21200$ & GEAR CRANK & 3510 & 2,106 & 5617 \\
8 & $105400-44250$ & COVER,RADIATOR & 3337 & 952 & 4289 \\
9 & $10540 \mathrm{G}-44340$ & SCREEN,(OFW) & 3337 & 952 & 4289 \\
10 & $105300-44460$ & COLLAR COV.RAD & 6361 & 6,916 & 13276 \\
11 & $105302-55240$ & STAY,FO TANK & 3119 & 1,663 & 4782 \\
12 & $28110-190220$ & SPANNER 19X22 & 5180 & 4,587 & 9767 \\
13 & $28110-140170$ & SPANNER 14X17 & 5180 & 4,587 & 9767 \\
14 & $105370-55710$ & ELEMENT,FO STR & 4901 & 4,106 & 9008 \\
15 & 10530 G-01480- & CYL.REAR COVER & 3510 & 2,106 & 5617 \\
16 & $105300-44940$ & TENS.PULLEY & 3337 & & 4289 \\
\hline
\end{tabular}




\section{Perbandingan Biaya Total Dengan EOQ dan Tanpa EOQ}

Tabel 7. Perbandingan Biaya Total Dengan dan Tanpa Metode EOQ (dalam Rp)

\begin{tabular}{|c|c|c|c|c|}
\hline No. & Nama Material & $\begin{array}{c}\text { Biaya Total } \\
\text { Tanpa Metode } \\
\text { EOQ }(\mathbf{R p}) \\
\end{array}$ & $\begin{array}{c}\text { Biaya Total } \\
\text { Dengan Metode } \\
\text { EOQ }(\mathbf{R p}) \\
\end{array}$ & $\begin{array}{c}\text { Selisih } \\
\text { Biaya (Rp) }\end{array}$ \\
\hline 1 & RAD.CMP & $2,971,760,537$ & $2,960,897,762$ & $10,862,775$ \\
\hline 2 & FO TANK & $1,095,659,346$ & $1,091,654,346$ & $4,005,000$ \\
\hline 3 & SILENCER ASSY & $459,826,648$ & $459,048,148$ & 778,500 \\
\hline 4 & DRAIN COCK,HRL & $435,166,579$ & $434,867,329$ & 299,250 \\
\hline 5 & V-PULLEY RAD & $398,613,521$ & $398,243,396$ & 370,125 \\
\hline 6 & $\begin{array}{l}\text { GOVERNOR } \\
\text { LEVER }\end{array}$ & $312,184,720$ & $310,339,720$ & $1,845,000$ \\
\hline 7 & GEAR CRANK & $263,076,857$ & $261,427,877$ & $1,648,980$ \\
\hline 8 & COVER,RADIATOR & $224,811,788$ & $222,640,538$ & $2,171,250$ \\
\hline 9 & SCREEN,(OFW) & $166,615,119$ & $166,341,046$ & 274,073 \\
\hline 10 & COLLAR COV.RAD & $132,743,585$ & $132,678,335$ & 65,250 \\
\hline 11 & STAY,FO TANK & $153,591,583$ & $153,055,633$ & 535,950 \\
\hline 12 & SPANNER 19X22 & $126,922,373$ & $126,827,873$ & 94,500 \\
\hline 13 & SPANNER 14X17 & $95,645,074$ & $95,573,861$ & 71,213 \\
\hline 14 & ELEMENT,FO STR & $101,177,561$ & $100,871,561$ & 306,000 \\
\hline 15 & CYL.REAR COVER & $78,635,169$ & $78,255,819$ & 379,350 \\
\hline \multirow[t]{2}{*}{16} & TENS.PULLEY & $92,311,702$ & $91,904,745$ & 406,958 \\
\hline & & $7,108,742,160$ & $7,084,627,988$ & $24,114,173$ \\
\hline
\end{tabular}

\section{Perbandingan Total Biaya Dengan EOQ dan Tanpa EOQ}

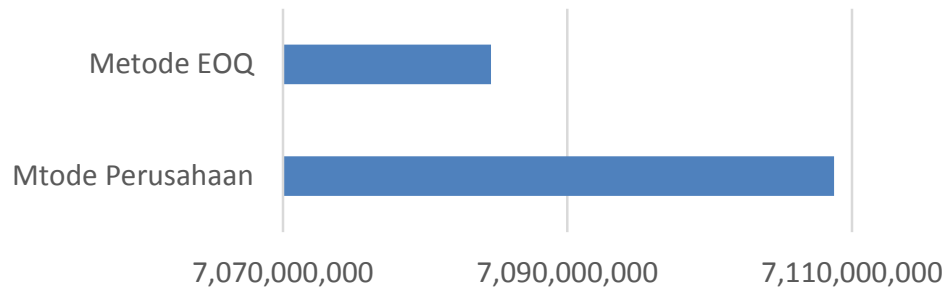

Gambar 2. Perbandingan Total Biaya Dengan EOQ dan Tanpa EOQ 
Dengan menggunakan metode EOQ untuk keenam belas material yang paling besar konstribusinya terhadap total biaya persediaan, PT.X dapat melakukan penghematan sebesar Rp. 24.114.173. Maka PT. X akan memperoleh keuntungan yang lebih besar mengingat material yang digunakan beragam. PT.X dapat mengalokasikan kelebihan biaya untuk keperluan lain. Metode ini juga menguntungkan perusahaan karena mudah dalam pelaksanaannya.

\section{Kebijakan Strategi Perusahaan}

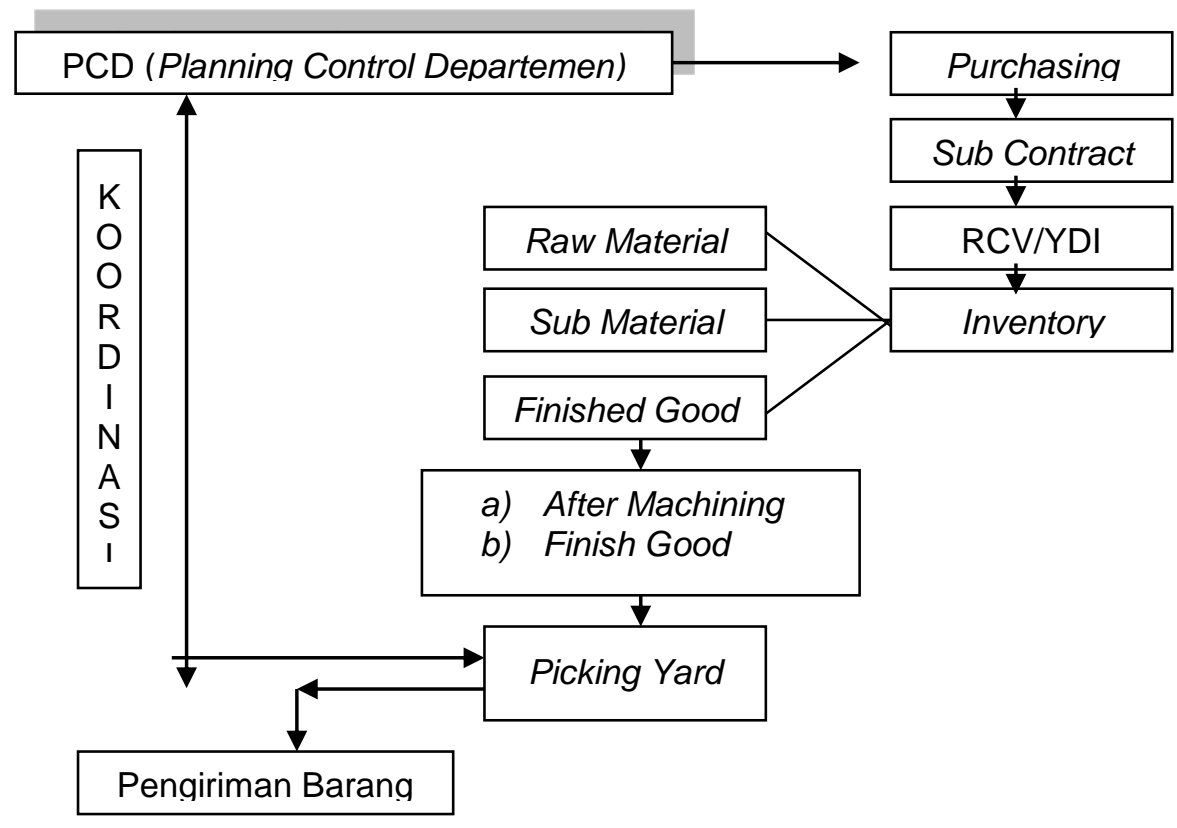

Gambar 3. Flow Supply Chain PT. X

Adapun kebijakan yang harus dilakukan perusahaan untuk mengoptimalkan persediaan yang sangat erat kaitannya dengan proses bisnis perusahaan selain mengaplikasikan metode EQ adalah dengan memaksimalkan fungsi pengawasan didalam Planning Control Department, agar alur material dari vendor bisa diaplikasikan dengan baik ditiap-tiap departemen di Perusahaan X sesuai dengan flow supply chain di gambar 3 diatas.

\section{PENUTUP}

\section{Simpulan}

Berdasarkan uraian diatas maka simpulan dari kebijakan pengawasan persediaan (inventory control) pada PT. X, yaitu:

1) Dari hasil perhitungan dengan menggunakan EOQ yang telah diterapkan pada material lokal kelompok A, pengeluaran dapat dihemat sebesar Rp. 24.114.173 dari biaya total yang dikeluarkan PT. X dalam setahun (selama periode tahun 2015).

2) Penjualan produk mesin diesel khusus model TF 85 MLY lebih besar tingkat permintaannya, yaitu mencapai 9.306. Sangat besar dibandingkan dengan model mesin diesel lainnya yang dihasilkan oleh perusahaan $\mathrm{X}$.

3) Hasil perhitungan dengan atau tanpa menggunakan metode EOQ yang tidak terlalu signifikan, turut dipengaruhi oleh penerapan kebijakan PT. X dengan para pemasoknya yang belum sesuai, oleh karena masih banyaknya supplier yang tidak memenuhi standar PT. X baik dalam hal pengiriman maupun technical.

Saran

Adapun rekomendasi (saran) yang dapat diberikan adalah sebagai berikut: 
1) PT. X sebaiknya menggunakan metode EOQ karena meskipun hasil perhitungan EOQ tidak terlalu signifikan memberikan keuntungan bagi perusahaan, namun jika metode EOQ diterapkan pada semua jenis material yang ada di PT. X, maka pengehematan yang lebih besar dapat diperoleh, mengingat untuk menghasilkan satu mesin diesel membutuhkan material yang beragam. Besarnya metode yang dapat dihemat dapat dialokasikan oleh perusahaan untuk keperluan lainnya, seperti penyediaan gudang baru mengingat mesin diesel model TF 85 MLY yang banyak permintaannya.

2) Permintaan TF 85 MLY yang jelas sudah banyak sekali permintaannya selama periode tahun 2015, dapat diikuti oleh model-model mesin diesel model lainnya, sehingga penjualan tidak hanya mendukung aplikasi pertanian saja. Inovasi produk dalam aplikasi seprti kelautan dan industri perlu dikembangkan.

\section{DAFTAR PUSTAKA}

Barry Jay R.Heizer.(2005) Operation Managemet. Edisi ke-7. Terjemahan, Penerbit: Salemba Empat

Donald J.Bowersox (2002). Manajemen Logistik. PT. Bumi Aksara

Freddy Rangkuti (2004). Manajemen Produksi: Aplikasi di bidang besar. PT. Raja Grafindo Perkasa

Hani Handoko (2000). Dasar-dasar Manajemen Produksi dan Operasi: Edisi Perata. Yogyakarta: BPEE.

James H. Greene, Ph.D (1974). Production and Inventory Control (Revised Edition). Richard D. Irwin, Inc, Homewood Ilionis

Nyoman Pujawan. (2005). Supply Chain Management. Jakarta. Penerbit: Guna Widya.

Sofyan Assauri (2004). Manajemen Produksi dan Operasi. Jakarta. Fakultas Ekonomi Universitas Indonesia.

Sudana, I Made. (2011). Manajemen Keuangan Perusahaan: Teori dan Praktik. Jakarta: Erlangga

Indroprasto, Erma Suryani (2012); Analisis Pengendalian Persediaan Produk Dengan Metode EOQ Menggunakan Algoritma Genetika untuk Mengefesienkan Biaya Persediaan; Jurnal ITS Vol 1 (Sept 2012) ISSN: 2301-9271.

Sofyan, Diana K. (2013). Perencanaan dan Pengendalian Produksi. Yogyakarta: Graha Ilmu

Gede Agus Darmawan, Wayan Cipta, Ni Nyoman Yulianthin (2015); Penerapan Economic Order Quantity (EOQ) Dalam Pengelolaan Persediaan Bahan Baku Tepung Pada Usaha Pia Ariawan di Desa Banyuning Tahun 2013; e-Journal Bisma Universitas Pendidikan GaneshaJurusan Manajemen (Volume 3 Tahun 2015).

Candra Yuliana, Topowijono,, Nengah Sudjana (2016); Penerapan Model EOQ (Economic Order Quantity) Dalam Rangka Meminimumkan Biaya Persediaan Bahan Baku (Studi Pada UD. Sumber Rejo Kandangan-Kediri); Jurnal Administrasi Bisnis (JAB)|Vol. 36 No. 1 Juni 2016 